\title{
Leveraging prospective teachers' knowledge through their participation in lesson study
}

\author{
Gloriana González ${ }^{1}$ (D) - Wanda Villafañe-Cepeda ${ }^{2} \cdot$ Omar Hernández-Rodríguez $^{3}$
}

Accepted: 11 October 2021 / Published online: 21 October 2021

(c) The Author(s), under exclusive licence to Springer Nature B.V. 2021

\begin{abstract}
This study focuses on a lesson study adaptation for bridging prospective teachers' experiences in a methods course and their field experiences in a teacher education program in Puerto Rico. We ask, what opportunities for teacher learning emerge during discussions in lesson study? Two lesson study teams of secondary mathematics prospective teachers, each led by an experienced mentor, planned technology-based lessons. Using the theoretical framework for lesson study by Lewis and colleagues, we analyzed video recordings of the teams' discussions. The results show learning opportunities in the three dimensions of the framework: teachers' knowledge and beliefs, the creation of a professional community, and the development of teaching-learning artifacts. The mentors leveraged prospective teachers' knowledge, built on topics discussed in the methods course, and created a professional learning community. Three resources introduced in the methods course supported the creation of a hybrid space connecting academic and practitioner knowledge: shared language about teaching moves for using technology in math instruction, the mathematical proficiency framework, and a lesson plan template. The mentors drew upon their subject matter and pedagogical knowledge during their facilitation of lesson study. The intervention exemplifies a lesson study adaptation that is feasible in the context of a teacher education program.
\end{abstract}

Keywords Lesson study · Prospective mathematics teachers · Professional learning · Teacher community · Mathematics content knowledge $\cdot$ Pedagogical content knowledge Technology to teach mathematics

Gloriana González

ggonzlz@illinois.edu

1 Department of Curriculum and Instruction, University of Illinois Urbana-Champaign, 387

Education Building, MC-708, 1310 South Sixth Street, Champaign, IL 61820, USA

2 Department of Programs and Teaching, University of Puerto Rico, Río Piedras, USA

3 Department of Graduate Studies, University of Puerto Rico, Río Piedras, USA 


\section{Introduction}

Many mathematics teacher education programs have adopted a practice-based orientation. This perspective acknowledges prospective teachers' need to develop knowledge, skills, and dispositions within specific teaching practices by developing a professional community (Ball \& Cohen, 1999). A practice-based approach involves situating teacher education activities in core activities of the teaching practice. For example, prospective teachers may examine videos of instruction in their methods course or lead class discussions of a homework assignment in a school setting. Traditionally, teacher education programs include a field experience component where prospective teachers learn to teach in a school under the mentorship of an experienced teacher. The standards from the Association of Mathematics Teacher Educators in the US promote that teacher education programs include field experiences in a consistent manner to build connections between methods courses taught at the university and authentic settings. The standards state, "An effective mathematics teacher preparation program supports candidates' engagement in increasingly comprehensive acts of teaching by providing coherent and developmentally appropriate clinical experiences" (Association of Mathematics Teacher Educators, 2017, Indicator P.4.2). ${ }^{1}$ The standards advocate gradually increasing prospective teachers' engagement by providing opportunities for building their teacher identity, arranging resources to examine teaching-and-learning issues, and coteaching lessons under the mentorship of an experienced mathematics teacher during field experiences early in the teacher education program.

Field experiences have the potential to ground prospective teachers' preparation in authentic issues of practice. Nevertheless, teacher education researchers have identified disconnects between methods courses taught at the university and school-based field experiences (Darling-Hammond et al., 2005). Prospective mathematics teachers learning to teach in novel ways that engage their students in meaningful math learning benefit from participating in teacher education programs that align the field experiences and methods courses (Clift \& Brady, 2005). Zeichner (2010) proposed creating hybrid spaces where academic and practitioner knowledge converge, thus providing opportunities for multiple sources of knowledge to be valued. In our work, we define hybridity as the space that is created by the intersection of various sources of teaching knowledge, including the knowledge of mathematics teacher educators, researchers in math education, mathematics teachers, and prospective mathematics teachers. ${ }^{2}$ Our work is aligned with Zeichner's (2010) definition of "third space as a lens to discuss various kinds of boundary crossings between campus and schools that are currently being enacted in teacher education programs across the United States" (p. 92). Following Bhabha (1990), the third space would allow for new positionings to emerge, revealing changes in traditional authority and power structures. This notion of hybrid spaces can be useful in redesigning teacher education programs by strengthening the connections between methods courses and field experiences.

In this study, we examine a lesson study adaptation that intended to connect a mathematics methods course and field experiences to answer the following overarching question:

\footnotetext{
1 In the U.S., the terms "clinical experience" and "field experience" are used interchangeably in reference to school-based experiences during a teacher education program. In this paper, we use the term "field experience.".

2 In the literature pertaining to hybridity, some scholars use the construct of the "third space" to denote the intersection of official and unofficial discourses regarding the production of new knowledge (see Gutiérrez, Baquedano, \& Tejada, 1999).
} 
What opportunities for teacher learning emerge during discussions in lesson study? By "opportunities for teacher learning," we refer to whether the activities and resources as well as the learning environment in a teacher education program allow prospective teachers to apprentice into teaching with the mentoring of experienced teachers and teacher educators (National Research Council, 2000). Lesson study is a professional development activity that originated in Japan that aims to improve teaching by increasing teachers' attention to student learning through their collective engagement in the process of planning, teaching, observing, and discussing a lesson (Fernandez, 2002). Mathematics teacher education programs have used lesson study, resulting in prospective teachers' increased attention to student thinking (Amador \& Carter, 2016), opportunities to create lessons centered on observations of students' thinking within a professional community (Fernandez \& Zilliox, 2011), growth in pedagogical content knowledge (Incikabi \& Kacar, 2017), and more noticing of instructional aspects related to student thinking (Bieda et al., 2015). Similar to Rasmussen's study (2016), the participants in our intervention did not have prior experience with lesson study. Through our lesson study adaptation, they were able to engage in various lesson study steps. We use the theoretical framework proposed by Lewis et al. (2009) to study our lesson study implementation in the context of a methods course.

\section{Theoretical framework}

Situated learning theory underlies the design of lesson study adaptation and, consequently, this study. Proponents of situated learning posit that learning is inherently connected to the context where it happens. Lave and Wenger (1991) argue that all activities are situated in particular contexts. A second important idea in their theory is that of "learning as legitimate peripheral participation" (Lave \& Wenger, 1991, p. 34). This notion primes opportunities for individuals to engage in constant negotiations with a community for participating in the activities that are particular to that community. According to Lave and Wenger, peripherality is a positive attribute since it acknowledges possible changes in the individual and in the community; the constant give-and-take between individuals allows them to constantly redefine the community where they belong. These communities are called communities of practice:

A community of practice is a set of relations among persons, activity, and world, over time and in relation with other tangential and overlapping communities of practice. A community of practice is an intrinsic condition for the existence of knowledge, not least because it provides the interpretive support necessary for making sense of its heritage. (p. 98)

Mathematics teachers belong to various communities of practice, including teachers with specialized knowledge for teaching mathematics, teachers in particular school settings (e.g., rural vs. urban settings, public vs. private schools, elementary vs. secondary schools), and users of particular curricular approaches (e.g., problem-based, technology-based, differentiated instruction). The knowledge generated by mathematics teachers reflects their intersections with these various contextually bound communities. The process of learning to be part of a practice is through apprenticeship (Lave \& Wenger, 1991). In teacher education programs, prospective teachers apprentice into teaching in their school-based field experiences through various activities where their knowledge of the school context is crucial (e.g., in lesson planning, leading class discussions, and preparing assessments). The 
situative perspective has influenced the design of mathematics teacher education programs, supporting prospective teachers' development of knowledge and beliefs that are aligned with current perspectives about mathematics teaching (Peressini et al., 2004).

We embrace the notion of creating hybrid spaces to build on the knowledge that prospective teachers bring to teacher education (Zeichner, 2010). Prospective teachers bring mathematical, pedagogical, and technological knowledge, as well as experiences learning mathematics and interacting with students. Prospective teachers' pedagogical knowledge is also special because of what Lortie (1975) called, "the apprenticeship of observation," which results in a vision of what teaching should look like from years of watching teachers as a student. The notion of hybrid spaces allows us to examine whether and how lesson study engages prospective teachers in apprenticing into teaching in a field experience setting by drawing on their knowledge and experiences, including those in the methods course. At the same time, the mentor teachers who supervise field experiences bring knowledge that uniquely positions them to create a hybrid space. For example, mentor teachers possess knowledge of their school's mathematics curriculum, students in their math classes, and instructional strategies. Additionally, mentor teachers' prior experiences supporting prospective teachers during field experiences contribute to their interactions with current prospective teachers. Overall, a hybrid space allows for the intersection of various sources of knowledge, thus validating teachers' practical knowledge about teaching, which is at times considered an "unofficial space" (Gutiérrez et al., 1999), and related to academic knowledge, at times considered the "official space."

We adopted the theoretical framework for lesson study by Lewis et al. (2009), which is aligned with a situative perspective on learning. Specifically, lesson study enables participation in a community of practice among teachers who are constantly considering the context where teaching happens. For example, Elipane's (2012) examination of prospective teachers' participation in lesson study revealed how they became more knowledgeable of their school's context and developed an inquiry stance within the school setting. Our study focuses on teacher learning opportunities during the lesson study meetings. According to the framework, lesson study has effects on three dimensions: (1) teachers' knowledge and beliefs, (2) teachers' professional community, and (3) teaching-learning resources. Each dimension has various subcategories. Within teachers' knowledge and beliefs, there are considerations of subject matter and pedagogical knowledge. In addition, this dimension includes developing an understanding of student thinking and establishing long-term goals for student learning in relation to instructional decisions. For example, when talking about an algebra lesson for teaching systems of linear equations, teachers can discuss various solution methods (subject matter knowledge of mathematics), how to sequence the introduction of those methods (pedagogical knowledge), and ideas for developing students' problem-solving skills (a long-term goal). The second dimension pertains to ways in which teachers are motivated to improve instruction and demonstrate mutual responsibility for providing high-quality instruction. Additionally, discussions about long-term goals for students are connected to the notion of building a professional community centered on students' learning. When teachers use a shared language in relation to teaching practices, they rely on terms known within the professional teaching community (Ball \& Forzani, 2011). For example, teachers could name specific teaching moves during a postlesson discussion, such as "launching a problem" or "revoicing" students' ideas, thus using shared language to analyze instruction. Finally, the third dimension pertains to the development of teaching-learning resources. This dimension is important since research on lesson study has demonstrated that artifacts are important for professional learning (Wake et al., 2016). The framework identifies that teaching-learning resources include tasks and lesson plans 
centered on student learning as well as protocols and resources that support teacher collaboration. For example, the design of a task that requires students to explain the meaning of the solution of a system of linear equations in the context of the problem would fall into this dimension. Another example is the implementation of lesson study protocols for recording changes to a lesson plan with justifications for those changes. Altogether, the dimensions in the framework helped us identify how lesson study can support instructional improvement to ultimately promote student learning.

\section{Research questions}

Two research questions guide our study:

1. What evidence of teacher learning opportunities is related to engagement in lesson study?

2. Does the evidence of teacher learning opportunities support the creation of a hybrid space connecting the methods course and the field experience? If so, how?

\section{Methods}

In this section, we describe the methods, including the lesson study intervention, the methods course, research participants, data collection methods, and analysis. We focus on the field experiences intended to bridge practice and theory.

\section{Research context}

The intervention was implemented as part of a secondary mathematics methods course in a four-year teacher education program at a public institution in Puerto Rico. The two-credithour course aimed at teaching prospective teachers, typically in the second semester of their third year in the program, to integrate technology and manipulatives in mathematics instruction. ${ }^{3}$ The course promoted prospective teachers' development of their technological pedagogical content knowledge (TPACK) (Harris et al., 2009; Koehler \& Mishra, 2005). Our work in the project involved three significant revisions to the methods course, mostly addressing the first seven weeks, which focused on uses of technology in math instruction. The first change was the introduction of the strands of mathematical proficiency (Kilpatrick et al., 2001) as a common theme throughout the course to anchor discussions about students' mathematical thinking. The strands of mathematical proficiency are five components to consider in relation to mathematical thinking: conceptual understanding, procedural fluency, strategic competence, adaptive reasoning, and productive disposition. The second change was the focus on open source interactive technology software packages through the introduction of Desmos (i.e., https://www.desmos.com/), an online graphing calculator.

\footnotetext{
${ }^{3}$ Even though the program's curricular sequence establishes that prospective teachers take the technology and manipulatives course in the second semester of their third year of the program, some prospective teachers take the course in their fourth year, while also taking a four-credit mathematics methods course with a required 40-h field experience component in a mathematics classroom.
} 


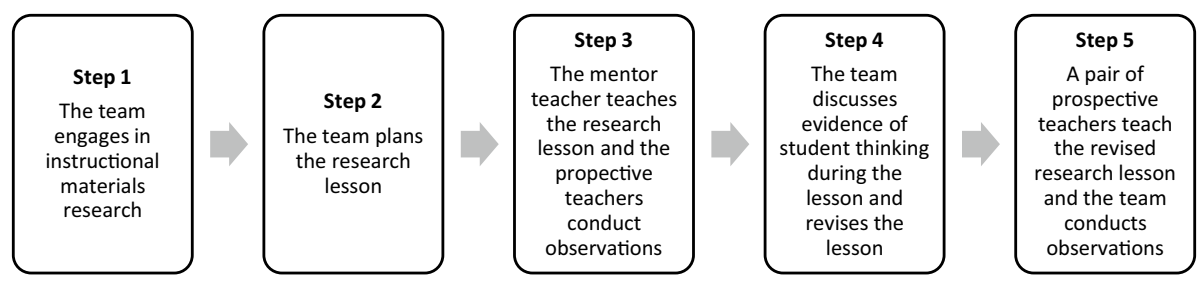

Fig. 1 Lesson study adaptation with prospective teachers

The prospective teachers had to design lessons using Desmos to promote mathematical proficiency and learn how to lead class discussions using students' ideas. A third change was the addition of a field experience component in a secondary mathematics classroom under the supervision of experienced mathematics teachers, namely, "mentors." The field experiences started with three required lesson observations in the assigned mentor's classroom, each focusing prospective teachers' attention on one strand of mathematical proficiency. ${ }^{4}$ The prospective teachers used a template provided in the methods course to record their observations. The observations also enabled the prospective teachers to get to know the school setting, the mentors, and their students prior to their engagement in lesson study. Lesson study teams with three-to-four prospective teachers and one mentor planned and taught a research lesson. According to our model, the mentor would teach the first version of the lesson, and a pair of prospective teachers would teach the revised version of the lesson to a new group of students. Figure 1 specifies the five lesson study steps: (1) conducting instructional material research, (2) planning the research lesson, (3) teaching the research lesson, (4) reflecting on the research lesson and revising the lesson, and (5) teaching the revised research lesson. The mentors played multiple roles, including team member, lesson study facilitator, and "knowledgeable other" (Takahashi, 2014), as they brought mathematical and pedagogical perspectives to the lesson study process. As part of the project, the research team developed various artifacts to support lesson study implementation, including a lesson plan template that was introduced in the methods course, observation protocols for the research lesson, and reflection prompts for journal entries, following Bieda et al. (2015) lesson study implementation in a mathematics methods course. Additionally, the research team created a rubric identifying teaching moves when teaching with Desmos, with the goal of providing prospective teachers with a decomposition of practice (Grossman et al., 2009) for learning how to teach, such as Herbst's (2011) rubric for managing classroom discourse.

This study uses data from the spring 2020 semester. There were 11 prospective teachers in the methods course, and all agreed to participate in the study. Most of the prospective teachers had completed their required math courses, including Calculus I and II, College Geometry, Statistics, and Discrete Mathematics. Three lesson study teams were created, according to the prospective teachers' availability to conduct field experiences. The COVID-19 pandemic affected the teams' engagement in lesson study as we had planned. One team (Team C) was unable to get started, but the other two teams (A and B) went through various lesson study steps. Our study focuses on Teams A and B. Team A,

\footnotetext{
${ }^{4}$ Because of the limited time available for the field experiences, the observations focused solely on three of the five strands: conceptual understanding, procedural fluency, and strategic competence.
} 
led by Mr. Martínez, planned the lesson but was unable to implement it. ${ }^{5}$ Team B achieved step four, where the team reflected on the lesson taught by Mr. García, the mentor, and revised the lesson.

The field experiences took place at a public secondary school serving approximately 500 students from 7 to 12th grade. The two mentors, Mr. García and Mr. Martínez, had experience mentoring prospective teachers, including supervising prospective teachers during their student-teaching internship. ${ }^{6}$ Both mentors lead professional development workshops for teachers and are proficient in using technology; they often teach technologybased lessons for their students and keep up to date with the educational technology trends. The field experiences were situated in an Algebra I class taught by Mr. Martínez to 8th graders and a Geometry class taught by Mr. García to 10th graders. ${ }^{7}$ The mentors did not have prior experience with lesson study or Desmos. The research team held weekly study group meetings with the mentors that included workshops for learning to use Desmos, an introduction to lesson study, and discussions of the methods course content. In addition, the research team provided the mentors resources for lesson study, including templates for meeting agendas, and suggested roles for supporting collaboration among the team members. The prospective teachers were mostly in their third year of the program (Table 1). A survey distributed among the prospective teachers at the beginning of the semester revealed that they had positive attitudes toward integrating technology in math instruction, but had limited exposure to technology in their school and college math courses and did not know of interactive calculators prior to the methods course (Choque-Dextre et al., 2020).

\section{Data collection}

Most of the meetings were video-recorded using the mentors' computers and an external camera when the meetings were at the mentors' classroom. ${ }^{8}$ The mentors saved the various versions of the lesson plans and related materials, such as the Desmos slideshows. In addition, the research team gathered artifacts from the lessons, such as prospective teachers' lesson observations and journal entries. In Table 2, we list the meetings and relevant information about the lesson study steps. The video recordings of the meetings were the main data sources for the analysis.

\section{Methods of analysis}

The first author produced a timeline of each meeting using the video-recording from the camera that captured all the participants' interactions, following protocols established

\footnotetext{
5 We use pseudonyms for the mentors and the prospective teachers.

6 In typical teacher education programs in the U.S., prospective teachers engage in a semester-long internship in a school under the supervision of a mentor teacher with regular evaluations by university faculty.

7 The school where the study was conducted follows the typical U.S. math curriculum, which allocates year-long courses to specific math topics such as algebra and geometry.

8 Team B's two initial meetings were not video-recorded, and we relied on the meeting notes. Mr. García decided to convene the meetings immediately after the prospective teachers conducted two of the required lesson observations. In the first meeting, Mr. García provided course materials (e.g., the syllabus and access to an electronic version of the textbook), created a shared drive for archiving material, and identified a course unit that prospective teachers had to read prior to the following meeting. In the second meeting, the team discussed topics in the course syllabus and considered how to use Desmos for teaching dilations.
} 


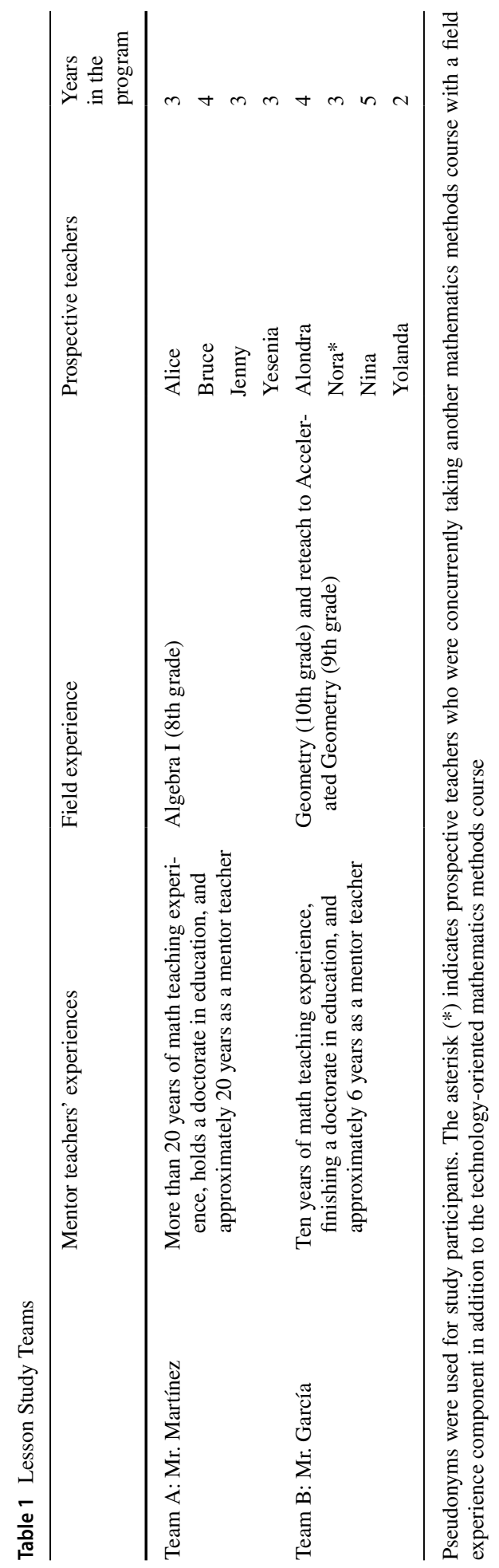


Table 2 Lesson Study Meetings

\begin{tabular}{lllll}
\hline & Meeting No & Date & $\begin{array}{l}\text { Lesson Study } \\
\text { Step }\end{array}$ & Duration (hr:min:s) \\
\hline \multirow{2}{*}{ Team A } & 1 & February 20, 2020 & 1 & $0: 48: 00$ \\
& $2^{\mathrm{a}}$ & February 27, 2020 & 2 & $0: 43: 50$ \\
& $3^{\mathrm{a}}$ & February 27, 2020 & 2 & $0: 07: 20$ \\
& $4^{*}$ & March 12, 2020 & 2 & $1: 43: 00$ \\
Team B & $1^{\mathrm{b}}$ & February 11, 2020 & 1 & Not available \\
& $2^{\mathrm{b}}$ & February 18, 2020 & 1 & Not available \\
& $3^{*}$ & March 5, 2020 & 2 & $0: 54: 47$ \\
& $4^{*}$ & March 10, 2020 & 2 & $0: 18: 20$ \\
& $5^{\mathrm{c}}$ & March 12, 2020 & 2 & $0: 24: 40$ \\
& $6^{\mathrm{c}}$ & March 12, 2020 & 4 & $0: 18: 00$ \\
\hline
\end{tabular}

Online meetings are indicated with an asterisk $(*)$

${ }^{\text {a }}$ The meetings happened at different times on the same day

${ }^{\mathrm{b}}$ The meetings were not video recorded

${ }^{\mathrm{c}}$ The meetings were before and after teaching the research lesson

Table 3 Descriptive Statistics of Lesson Study Meetings

\begin{tabular}{lllll}
\hline Team & Meeting No & $\begin{array}{l}\text { No. of } \\
\text { Inter- } \\
\text { vals }\end{array}$ & $\begin{array}{l}\text { Mean duration } \\
\text { per interval } \\
\text { (min:s) }\end{array}$ & $\begin{array}{l}\text { Median duration } \\
\text { per interval } \\
\text { (min:s) }\end{array}$ \\
\hline A & 1 & 12 & $4: 08$ & $3: 17$ \\
A & 2 & 10 & $4: 31$ & $4: 20$ \\
A & 3 & 2 & $3: 42$ & $3: 42$ \\
A & $4^{\text {a }}$ & 25 & $4: 15$ & $4: 10$ \\
B & $3^{\text {b }}$ & 9 & $6: 01$ & $2: 37$ \\
B & 4 & 7 & $2: 44$ & $2: 10$ \\
B & 5 & 12 & $2: 09$ & $1: 35$ \\
B & 6 & 8 & $2: 31$ & $2: 10$ \\
\hline
\end{tabular}

We only analyzed meetings that were video recorded

${ }^{a}$ Team A restarted the online session approximately seven min into the meeting, because one prospective teacher had difficulties getting access. We combined the two video recordings, since these are records of the same meeting

${ }^{\mathrm{b}}$ Team B spent $19 \mathrm{~min}$ and $20 \mathrm{~s}$ in one interval finding a common time for a future meeting, which explains the difference between the mean and the median duration of intervals

by Herbst et al. (2011). The timeline segments the video into intervals according to changes in the activity structure of the meeting, such as fixing a particular slide for the lesson or solving a math problem on the board, with an overlap as participants transition from one activity to the next. The unit of analysis in our study is an interval. Table 3 includes descriptive statistics about the intervals per meeting. 
We coded each interval, in relation to whether there was evidence of learning opportunities along the three dimensions in the discussions, using binary coding (i.e., 1 for evidence and 0 for no evidence). In the coding template, each coder wrote the justifications for their coding, specifying instances in the discussion to support coding decisions. A coding of 1 for any of the subcategories of the dimension resulted in a coding of 1 for the dimension, signaling the existence of evidence along one of the features of the dimension. Our individual notes and subsequent discussions during research meetings allowed us to match our coding and evidence from the videos.

After discussing the framework, the three authors independently coded Team B's third meeting. Our coding disagreements mostly pertained to the third dimension of teaching and learning resources. We refined our understanding of these codes. For example, we established distinctions between discussions about the task and the lesson plan by considering that changes to the task are about one specific exercise or activity, whereas changes to the lesson plan affect the entire lesson, such as the sequencing of the activities. Similarly, references to "tools" in this dimension go beyond the use of interactive technologies for teaching, which affect students. Instead, this code pertains to tools for sharing resources or ideas among teachers, such as the use of publishing resources from Desmos to share slides during lesson planning or the use of a common lesson plan template provided in the methods course. We decided to continue to code each lesson study meeting by two coders and resolve disagreements during research meetings, with the third member of the research team becoming the tie-breaker when needed. We achieved substantial interrater reliability for the categories and subcategories when independently coding all of the meetings. We used IBM SPSS Statistics (Version 28) to calculate Cohen's Kappa (Siegel \& Castellan, 1988). The Kappa statistics were as follows: 0.814 for teachers' knowledge and beliefs, 0.738 for teachers' professional community, and 0.746 for teaching-learning resources; $p<0.001$ for all categories. ${ }^{9}$ Table 4 shows an explanation of the codes and examples from the data. In a final step, we selected intervals with examples from various dimensions of the framework, with the purpose of building the two cases about the lesson study implementation. We transcribed and translated from Spanish to English relevant excerpts from those intervals.

\section{Examples of coding}

To illustrate the analysis, we select an example from the data and discuss our coding decisions. In Team A's second meeting, interval 6, which began 24 min and 50 s into the meeting and had a duration of $4 \mathrm{~min}$ and $40 \mathrm{~s}$, we found evidence for learning opportunities along two categories: teachers' knowledge and beliefs and teaching-learning resources. Mr. Martínez selected a task from an algebra textbook requiring students ${ }^{10}$ to find the

\footnotetext{
9 The Kappa statistics for the subcategories were .782 for subject matter knowledge, 920 for pedagogy, .894 for student thinking and how to capture it, .902 for long-term goals for student development and how they connect to daily instruction, .607 for motivation and capacity to improve instruction, .607 for mutual accountability, .661 for shared long-term goals, .706 for shared languages, processes, and frameworks for analyzing instruction, .706 for tasks that reveal student thinking, 1 for data collection protocols, .674 for tools that support productive exchange of ideas, and .641 for lesson plans that promote student learning; $p<.001$ for all subcategories.

${ }^{10}$ We use the term "students" in reference to the students in the Algebra I or Geometry courses in the mentors' classrooms.
} 


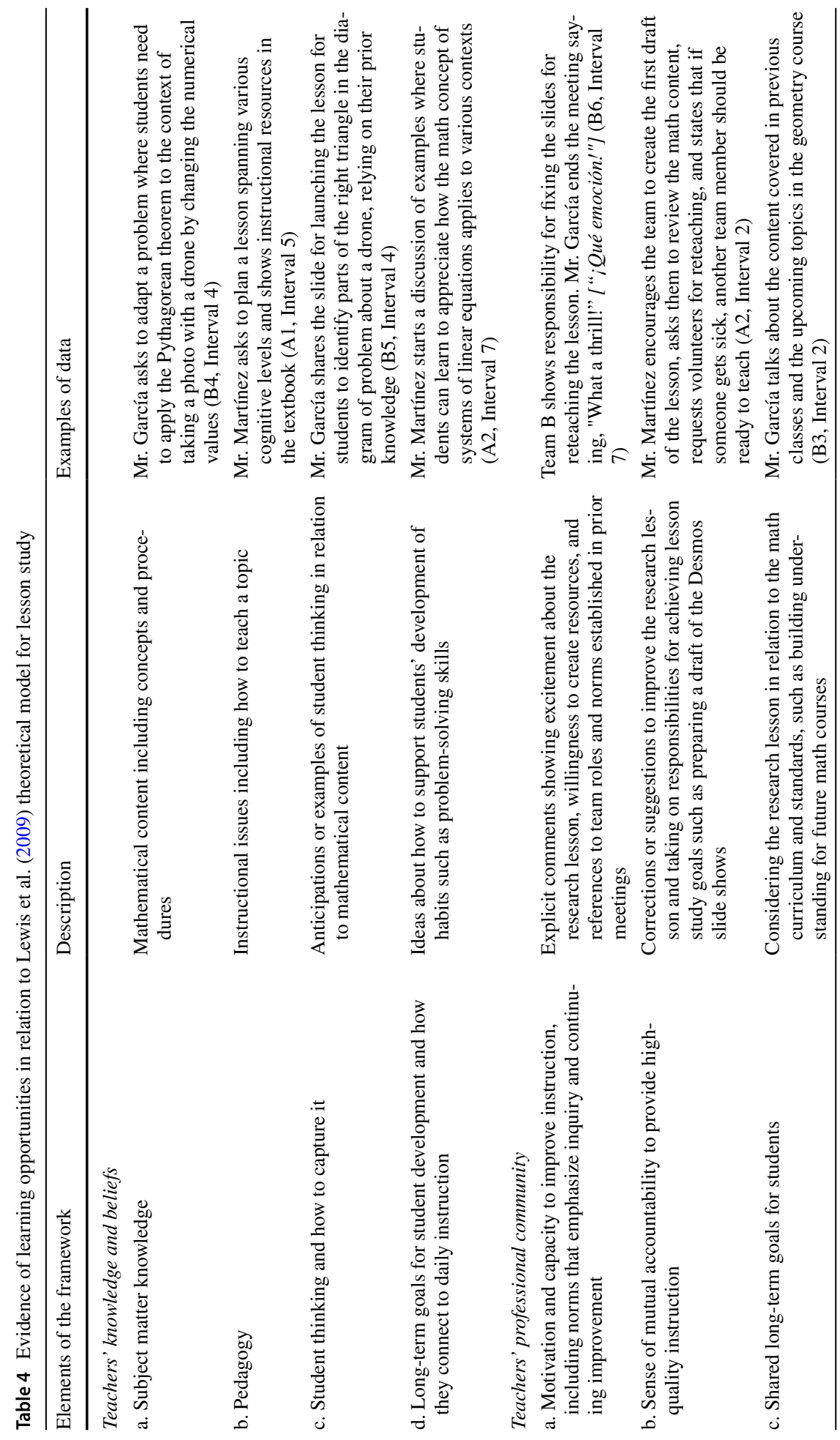




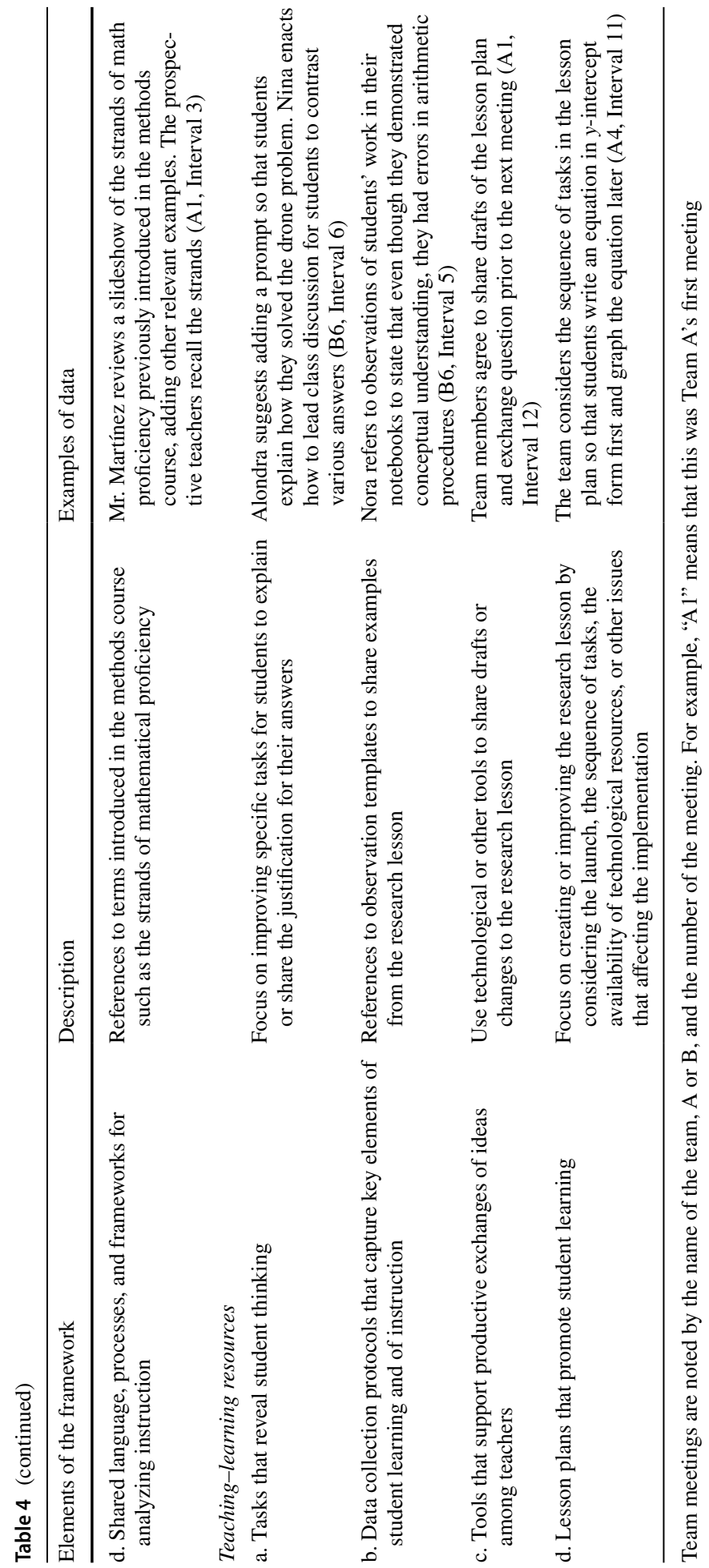


solution of a system of linear equations by making a table. The task was situated in the context of two siblings, each with a comic book collection, with initial amounts of 15 and seven comic books, and with additions of two and four books per month, respectively. Mr. Martínez asked the prospective teachers if they knew how to build a table of values in Desmos, and they replied that they did not know how to do so. Mr. Martínez demonstrated how to create a table of values in Desmos by opening a new file and creating a table with three columns for $x, y=2 x+15$, and $y=4 x+7$, respectively, next to a Cartesian plane. Mr. Martínez said that students could start predicting the solution by plotting solutions for each equation on the plane. Then Mr. Martínez shifted the discussion to using Desmos features for predicting the solution of the system, changing the context to one about predicting when two bank accounts will have the same balance. Mr. Martínez said that students could use the "sketch" feature to predict the point of intersection, giving examples of possible students' answers and how to lead a class discussion of students' solutions. Mr. Martínez talked about using the "overlay" feature for overlapping students' answers and checked if the points chosen by students were concurrent without disclosing the identity of students whose predictions were not concurrent. Mr. Martínez anticipated that students could propose a graphical solution drawing on their knowledge of the $y$-intercept form of a linear equation. In terms of teacher knowledge and beliefs, we found evidence of subject matter knowledge in the discussion of the concept and procedures involved when solving systems of linear equations. We also found evidence of pedagogy, since Mr. Martínez did what Horn (2010) calls the "re-visioning" of practice by anticipating how to lead a discussion of various students' predictions of the intersection point. Mr. Martínez anticipated student thinking by considering possible errors that could surface when predicting the intersection point. However, we did not find evidence of long-term goals for students, such as how to translate contextual information in a problem into a table or equation. Mr. Martínez modeled how to create a technology-based task where students could show their thinking by sketching points in Desmos, or showing the equations of the line, and consequently assess students' mathematical understanding. Therefore, we found evidence of tasks that reveal student thinking within the dimension of teaching-learning resources. Nevertheless, we did not find evidence in the interval about promoting a professional community. Evidence for this dimension could involve proposing new ideas for the research lesson, a shared sense of responsibility when adapting the task using Desmos, explicit references to long-term goals such as promoting students' problem-solving skills, or references to the strands of mathematical proficiency, which is shared language introduced in the methods course.

\section{Results}

We start with an overview of the results regarding learning opportunities for the prospective teachers. We focus on discussions during the planning step for which we had evidence from both teams. Finally, we answer the second research question regarding evidence for creating a hybrid space by focusing on the subcategories of the framework. In characterizing each team's discussions, our goal is not to compare the teams or to identify the "best" discussions. Instead, we aim to examine how our lesson study adaptation opened opportunities for teacher learning along the three dimensions during each step, and subsequently we contextualize the evidence in relation to each team's decisions regarding the research lesson. 
Table 5 Number of intervals with evidence of teacher learning opportunities

\begin{tabular}{|c|c|c|c|c|c|}
\hline \multirow[t]{2}{*}{ Team meetings } & \multirow{2}{*}{$\begin{array}{l}\text { Lesson } \\
\text { Study step }\end{array}$} & \multirow{2}{*}{$\begin{array}{l}\text { No. of intervals } \\
\text { in the meeting }\end{array}$} & \multicolumn{3}{|l|}{ Dimension } \\
\hline & & & $\begin{array}{l}\text { Teachers' knowl- } \\
\text { edge and beliefs }\end{array}$ & $\begin{array}{l}\text { Teachers' profes- } \\
\text { sional community }\end{array}$ & $\begin{array}{l}\text { Teaching } \\
\text { and learning } \\
\text { resources }\end{array}$ \\
\hline A1 & 1 & 12 & $3(25 \%)$ & $9(75 \%)$ & $9(75 \%)$ \\
\hline A2 & 2 & 10 & $5(50 \%)$ & $5(50 \%)$ & $8(80 \%)$ \\
\hline A3 & 2 & 2 & $2(100 \%)$ & $2(100 \%)$ & $1(50 \%)$ \\
\hline A4 & 2 & 25 & $18(72 \%)$ & $15(60 \%)$ & $20(80 \%)$ \\
\hline Team A's total & & 49 & $28(57 \%)$ & $31(63 \%)$ & $38(78 \%)$ \\
\hline B3 & 2 & 9 & $5(56 \%)$ & $7(78 \%)$ & $6(67 \%)$ \\
\hline B4 & 2 & 7 & $3(43 \%)$ & $4(57 \%)$ & $2(29 \%)$ \\
\hline B5 & 2 & 12 & $10(83 \%)$ & $3(25 \%)$ & $3(25 \%)$ \\
\hline B6 & 4 & 8 & $6(75 \%)$ & $5(63 \%)$ & $6(75 \%)$ \\
\hline Team B's total & & 36 & $24(67 \%)$ & $19(53 \%)$ & $17(47 \%)$ \\
\hline
\end{tabular}

Team meetings are noted by the name of the team, A or B, and the number of the meeting. For example, "A1" indicates Team A's first meeting

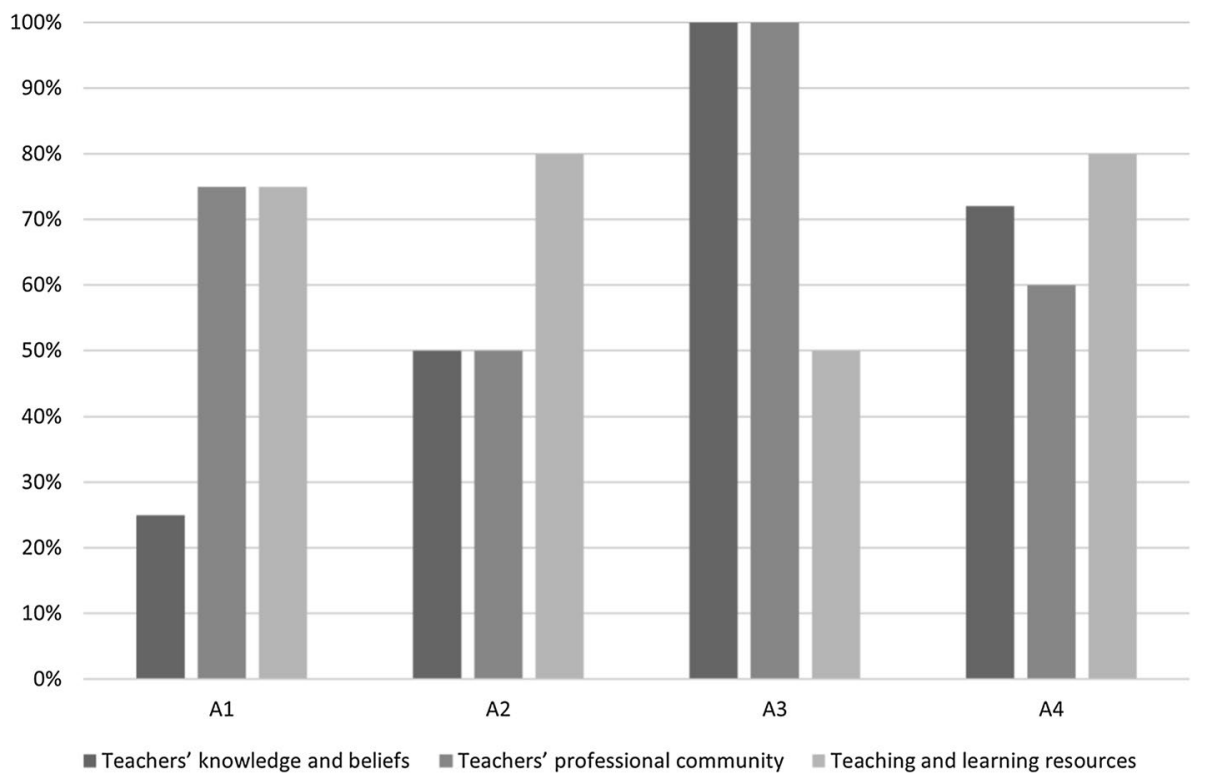

Fig. 2 Evidence of teacher learning opportunities in Team A's meetings, "A1" denotes the first meeting, "A2" the second meeting, and so forth

\section{Teacher learning opportunities in lesson study}

Table 5 shows that in all of the meetings, there was evidence of opportunities for teacher learning along the three dimensions. Team A had the most intervals with 


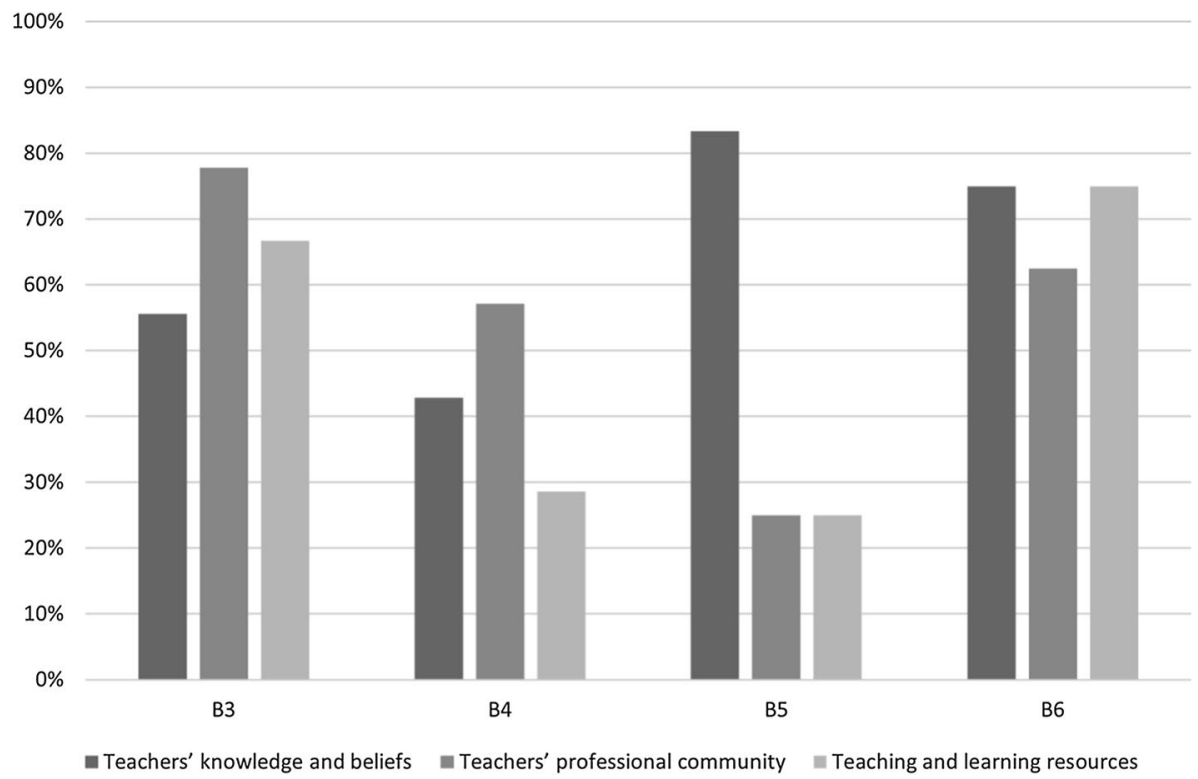

Fig. 3 Evidence of teacher learning opportunities in Team B's meetings, "B1" denotes the first meeting, "B2" the second meeting, and so forth

evidence of discussions about teaching and learning resources, followed by teachers' professional community and teachers' knowledge and beliefs. Team B had the most intervals with discussions about teachers' knowledge and beliefs, followed by teachers' professional community and teaching and learning resources.

Figures 2 and 3 show the percentage of intervals with evidence of teacher learning opportunities at each meeting along each dimension of the framework for Team A and Team B, respectively. During Team A's two initial meetings, there were more intervals devoted to discussions about teaching and learning resources. In their third meeting, the majority of Team A's intervals had evidence of discussions related to teachers' knowledge and beliefs and teachers' professional community. In Team A's fourth meeting, most of the discussions pertained to teaching and learning resources. Team A's prevalence of discussions about teaching and learning resources can be explained because they were creating materials for the research lesson. At the same time, discussions for building a professional community were sustained throughout Team A's meetings. Team B's discussions in the third and fourth meetings were mostly about building a professional community. In their fifth meeting, Team B's discussions centered on opportunities to further develop teachers' knowledge and beliefs. In the postlesson reflection, which was Team B's sixth meeting, $75 \%$ of the intervals had evidence of discussions pertaining to teachers' knowledge and beliefs and teaching and learning resources. Discussions pertaining to teachers' professional community constituted $63 \%$ of the intervals. The findings suggest that Team B's postlesson reflections integrated teacher learning opportunities in the three dimensions of the framework. 
Table 6 Number of intervals with evidence of teacher learning opportunities during planning meetings

\begin{tabular}{|c|c|c|c|c|}
\hline \multirow[t]{2}{*}{ Team meetings } & \multirow{2}{*}{$\begin{array}{l}\text { No. of intervals in } \\
\text { the meeting }\end{array}$} & \multicolumn{3}{|l|}{ Dimension } \\
\hline & & $\begin{array}{l}\text { Teachers' knowl- } \\
\text { edge and beliefs }\end{array}$ & $\begin{array}{l}\text { Teachers' profes- } \\
\text { sional community }\end{array}$ & $\begin{array}{l}\text { Teaching } \\
\text { and learning } \\
\text { resources }\end{array}$ \\
\hline A 2 & 10 & $5(50 \%)$ & $5(50 \%)$ & $8(80 \%)$ \\
\hline A3 & 2 & $2(100 \%)$ & $2(100 \%)$ & $1(50 \%)$ \\
\hline A4 & 25 & $18(72 \%)$ & $15(60 \%)$ & $20(80 \%)$ \\
\hline Team A's planning & 37 & $25(68 \%)$ & $22(59 \%)$ & $29(78 \%)$ \\
\hline B3 & 9 & $5(56 \%)$ & $7(78 \%)$ & $6(67 \%)$ \\
\hline B4 & 7 & $3(43 \%)$ & $4(57 \%)$ & $2(29 \%)$ \\
\hline B5 & 12 & $10(83 \%)$ & $3(25 \%)$ & $3(25 \%)$ \\
\hline Team B's planning & 28 & $18(64 \%)$ & $14(50 \%)$ & $11(39 \%)$ \\
\hline
\end{tabular}

Team meetings are noted by the name of the team, A or B, and the number of the meeting. For example, "A1" indicates Team A's first meeting

\section{Teacher learning opportunities when planning the research lesson}

Since the two teams differed in the distribution of the evidence available and the number of completed lesson study steps, we concentrate on planning (step 2), which both teams completed (see Table 6). Most of Team A's planning discussions were about teaching and learning resources (78\% of the intervals during planning meetings). Most of Team B's planning discussions provided learning opportunities pertaining to teachers' knowledge and beliefs (64\% of the intervals during planning meetings). In the following section, we elaborate the difference in learning opportunity dimensions by going into detail about each team's lesson study implementation. Looking at Team A, during the instructional materials research step, Mr. Martínez provided access to the teacher's edition of two Algebra I textbooks for prospective teachers to study how they introduced the main concepts pertaining to the topic of systems of linear equations. He taught them how to read instructional materials. For example, Mr. Martínez asked them to read the annotations in the margins of the teacher's edition of the textbooks, which includes suggestions for teaching and anticipations of possible student errors. He also taught the prospective teachers to map the Common Core State Standards (NGAC, 2010) to the Puerto Rico Mathematics Standards (Departamento de Educación de Puerto Rico, 2014) so that the research lesson would be anchored in relevant standards. Mr. Martínez asked students to consider attending to students' needs by differentiating their instruction. Additionally, Mr. Martínez asked the prospective teachers to include opportunities for students to develop their mathematical proficiency and made explicit references to the strands by reviewing the same slideshow that had been introduced in the methods course. Team A decided to focus on two of the five strands of mathematical proficiency, procedural fluency and productive disposition, and Mr. Martínez welcomed connections with other strands. ${ }^{11}$ Mr. Martínez's actions during the first meeting set up

\footnotetext{
11 Productive disposition is one of the strands of mathematical proficiency and involves the "habitual inclination to see mathematics as sensible, useful, and worthwhile, coupled with a belief in diligence and one's own efficacy" (Kilpatrick, Swafford, \& Findell, 2001, p. 5). The prospective teachers had studied the five strands of mathematical proficiency in the methods class even though, as we stated earlier, the lesson observations focused only on three of the strands: conceptual understanding, procedural fluency, and strategic competence.
} 


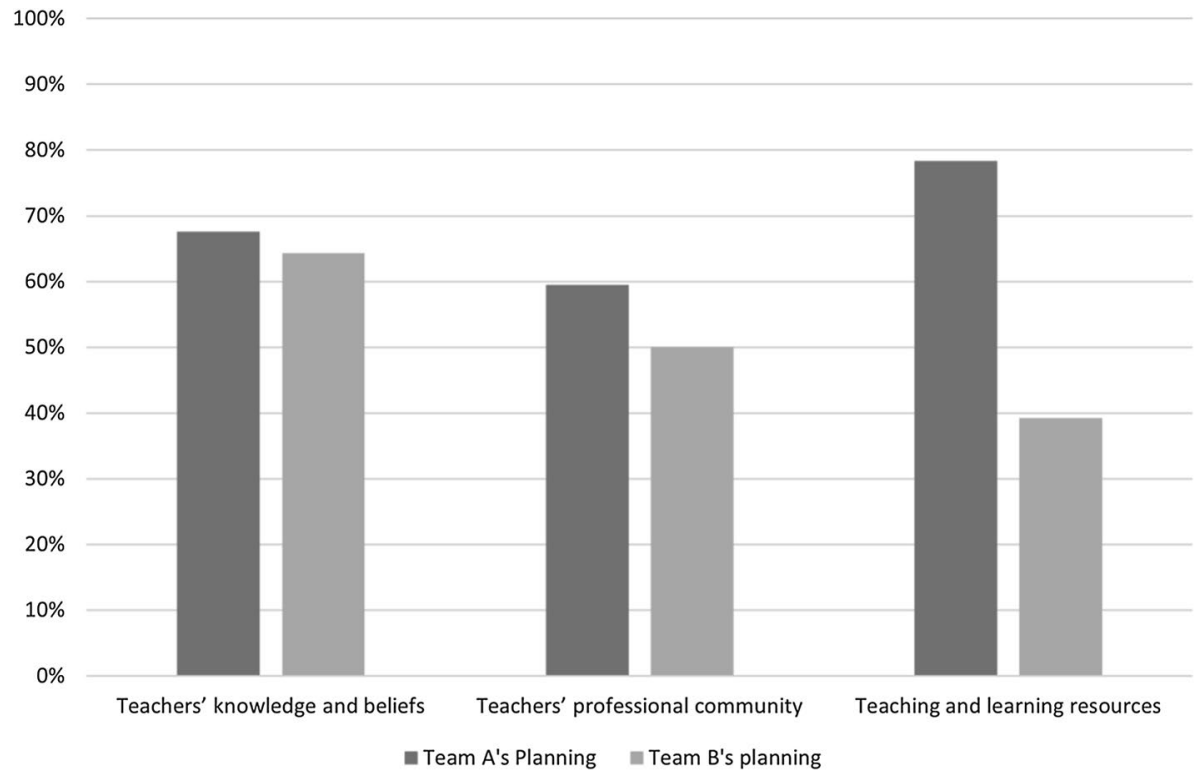

Fig. 4 Evidence of teacher learning opportunities in the planning meetings

the prospective teachers to prepare a draft of a research lesson using Desmos outside of the scheduled lesson study meetings. During the three subsequent meetings, Mr. Martínez spent time reviewing and making suggestions to the draft of the research lesson. Discussions about the teaching-learning resources, including changes to specific tasks and the overall lesson plan, accounted for $78 \%$ of the intervals of planning meetings. That is, the draft of the research lesson created by the prospective teachers anchored Team A's discussions during the second lesson study step. In the planning meetings, Mr. Martínez highlighted important mathematical concepts (e.g., the meaning of the solution of a system of linear equations), asked the prospective teachers to consider how to differentiate instruction, and illustrated possible student errors, using specific examples from the tasks that the prospective teachers had created. These comments were evidence of learning opportunities about teacher knowledge and beliefs in $68 \%$ of the intervals during the planning meetings. At the same time, there was evidence of opportunities for building a professional community in 59\% of the intervals of planning meetings, which was reflected in instances where team members showed their responsibility and took the initiative for planning parts of the research lesson. Figure 4 shows that more than $50 \%$ of all the intervals in Team A's planning meetings included discussions along each of the dimensions in the framework.

Team B had a different approach to the planning process. According to the records of the initial meetings, the team explored the possibility of teaching a research lesson about dilations or fractals. Nevertheless, their class observations prior to the lesson study cycle prompted them to consider changing the topic to one more aligned with required curricular content instead of an enrichment activity. In their first planning meeting, Mr. García shared a problem for students to apply the Pythagorean theorem and proportional reasoning in the context of using a drone to take a photo. The problem included a diagram where a drone was situated above a piece of land and there was a set of triangles showing the relationship between the camera lens in the drone and the piece of land photographed. Given some of 
the values in the proportion, students had to calculate the height of the drone. Most of the intervals during the planning meetings were devoted to discussing the mathematical content of the research lesson and the pedagogical decisions around using the drone problem. For example, the team made decisions about the numerical values for the exercises, scaffolding the introduction of square roots to ease students' opportunities to achieve procedural fluency. Mr. García also introduced a proof of the Pythagorean theorem that required establishing equivalent areas. In the discussion of the proof, Mr. García led the prospective teachers to anticipate possible student procedural errors with binomial expansion. There was evidence of opportunities for learning about teachers' knowledge and beliefs in $64 \%$ of the intervals devoted to planning the research lesson. In 50\% of the intervals for planning, there was evidence of the development of a professional community, mostly pertaining to motivation for improving instruction and a sense of accountability. For example, the prospective teachers showed enthusiasm and appreciation for learning the proof of the Pythagorean theorem that Mr. García had introduced and was new to them. There was evidence of discussions about teaching-learning resources in 39\% of the intervals devoted to planning, which could be explained because Mr. García produced a first draft of the research lesson that the prospective teachers modified. These modifications were not substantial. Some evidence along this dimension pertained to efforts to share instructional materials via online platforms, including opportunities to collaborate in editing the slides for the research lesson. It seems that since Mr. García produced a draft of the research lesson, the team's discussions concentrated on other dimensions of the framework.

Figure 4 shows that most of the discussions in Team A's planning meetings had teacher learning opportunities in relation to the development of teachers' knowledge and beliefs, in contrast with Team B's planning meetings, which were mostly about the development of teaching and learning resources. Since both teams had a different approach to planning, their discussions differed; Team A's discussions were mostly about preparing the tasks for the research lesson, and Team B's discussions were about the mathematical content of the lessons.

\section{Creating hybrid spaces for teacher learning}

Our second research question focuses on evidence about the creation of a hybrid space where discussions provide evidence of connections between the methods course and the field experiences through lesson study. Table 7 includes a detailed summary of the results, including the subcategories. We identified instances of hybridity in three subcategories. First, in some discussions of pedagogy, there were references to the teaching moves for using Desmos that had been introduced in the methods course. The identification of moments in the research lesson where they could incorporate a teaching move in relation to specific lesson objectives required applying TPACK. For example, in the fourth meeting, Mr. Martínez suggested changing a task by adding one of the Desmos moves introduced in the methods course which had been named as "overlay" (A4, Interval 13). Specifically, Mr. Martínez reviewed a slide where students were given a graph of two intersecting lines and they needed to answer a prompt asking them to determine the Cartesian coordinate that satisfied the system. Mr. Martínez noted that whoever teaches the research lesson could remind students verbally that the solution needed to make both equations true. He edited the slide so that students could enter the ordered pair as a math text. Then he suggested to delete a Desmos option for students to see other students' explanation of their answers that the prospective teachers had selected in that slide. Instead, Mr. Martínez said that students 


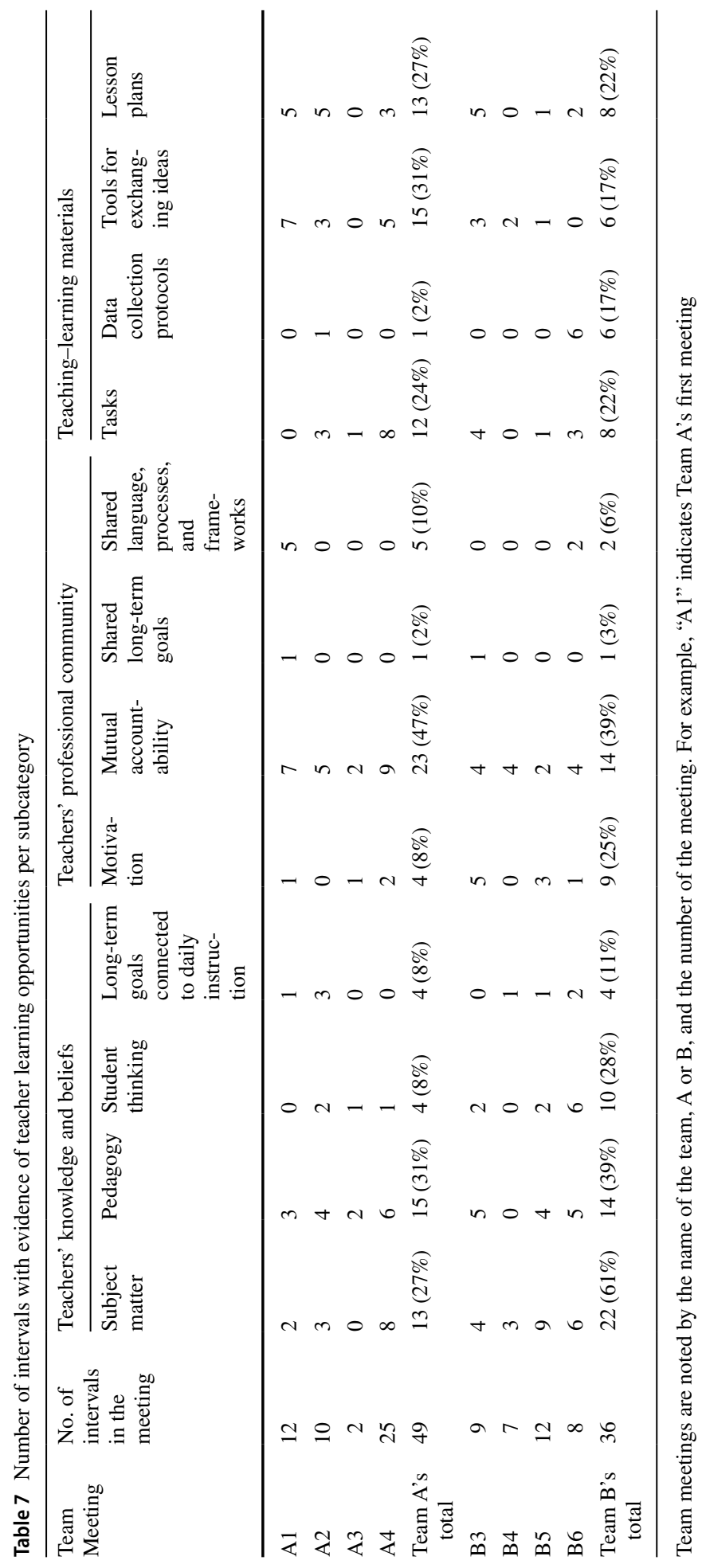


could submit their answers individually. Then the teacher could use Desmos to overlay students' individual solutions and lead a class discussion. Mr. Martínez said:

And there I would take away the "show students their classmates' responses" so that then later - because that part later when explaining the, the - when the activity is being carried out, you can overlap the images and see where were the points from all students and [that] can be used as a strategy for the discussion. (Translated by the authors)

[Y ahí yo le quitaría lo del "show students their classmates' responses" para que entonces luego-porque esa parte luego cuando se esté explicando el, el-cuando se esté llevando a cabo la actividad, se pueden solapar las imágenes y ver dónde quedaron los puntos de todos los estudiantes y se puede utilizar como una estrategia para la discusión.]

In this interval, we found evidence of creating a hybrid space by drawing explicit connections between teaching moves for using technology introduced in the methods course and the research lesson. Even though Mr. Martínez did not name the move as stated in the rubric provided in the methods course, "overlay," the change to the Desmos slide corresponded to what was discussed in the methods course. Mr. Martínez demonstrated having TPACK by the ease in which he edited the slides, making use of Desmos' features. Moreover, his idea to use the "overlay" move to prompt class discussions about their predictions when locating the solution in the graph shows a sophisticated view of technology for promoting students' conceptual understanding of the solution of a system of equations. In sum, the evidence pertaining to the pedagogy subcategory included instances where the teaching moves for integrating technology in math instruction that were introduced in the methods course were applied to the research lesson in the field experience.

A second source of evidence of hybridity in the lesson study discussions was by the use of shared language, processes, and frameworks. Specifically, the references to the strands of mathematical proficiency provided opportunities to connect the research lesson's objectives with the framework that had been introduced in the methods course. For example, as stated earlier, in their first meeting, Mr. Martínez asked the prospective teachers to identify two strands of mathematical proficiency that they would address in the lesson. Another example of references to the strands of mathematical proficiency occurred in Team B's debriefing meeting immediately after Mr. García taught the research lesson. Alondra suggested a modification to a multiple-choice task by adding a request for students to explain their reason for their answers. Yolanda stated that the modification could help to see students' ideas and whether they had a conceptual error (B6, Interval 3). Yolanda's comment showed a connection with the strands of mathematical proficiency by focusing on students' conceptual understanding. While there were few examples of uses of shared language and frameworks, there is potential in using the mathematical proficiency framework for bridging the methods course and the field experience. The use of terms for the technological moves provided in the rubric is another example of using shared language for creating a hybrid space for anticipating teaching moves in the lesson plan and identifying instances of teaching during the lesson observation.

A third source of evidence of creating a hybrid space was the use of the lesson plan template provided in the methods course. The lesson plan template required prospective teachers to specify how they would integrate Desmos in the lesson, formulate specific questions that they would ask students, anticipate students' responses, and provide examples of how to handle those responses. Alice reminded the team that they had to use the lesson plan 
template (A1, Interval 9). Prior research has documented how the lesson plan can serve as a boundary object, connecting various activities throughout lesson study (Wake et al., 2016). The prospective teachers in a Danish lesson study implementation also used a lesson plan template to make planning decisions explicit and detailed in relation to student learning goals (Rasmussen, 2016). In our case, the lesson plan template provided in the methods course helped to bridge their experiences planning the research lesson and the required elements for a technology-based lesson discussed in the methods course. In addition, the lesson plan template reinforced the use of shared language about the strands of mathematical proficiency and the moves for teaching with technology.

\section{Summary of teacher learning opportunities in the lesson study adaptation}

In summary, subcategories (1) pedagogy, (2) shared language, processes, and frameworks, and (3) lesson plans that promote student learning, all provided evidence of the creation of a hybrid space. The instances where the teams designed a lesson with Desmos exemplified TPACK, since none of the prospective teachers had knowledge of Desmos prior to their participation in the methods course. There is evidence of hybridity in their pedagogical choices by connecting the teaching moves for using technology in mathematics teaching that had been introduced in the methods course and their field experiences. The mathematical proficiency framework and the teaching moves for using technology exemplify shared language and framework. The lesson plan template emphasized the goal of promoting student learning by applying what was learned in the methods course. One possible reason for the evidence of hybridity within these subcategories is that they allowed us to see the application of tools to connect theory and practice, such as the mathematical proficiency framework and the lesson plan template. The theoretical framework for lesson study proposed by Lewis et al. (2009) allowed us to identify these tools for creating hybrid spaces.

\section{Discussion and conclusions}

The prospective teachers participating in our lesson study adaptation had opportunities for teacher learning in relation to teachers' knowledge and beliefs, teachers' professional community, and the creation of teaching and learning materials. By applying content introduced in the methods course to lesson study, the prospective teachers connected academic and practitioner knowledge. Specifically, the strands for mathematical proficiency framework guided their elaboration of the research lesson and focused their attention on creating tasks for promoting and revealing student thinking. The strands for mathematical proficiency also provided a shared language for attending to student thinking during lesson observations and sharing their observations during the postlesson reflection. In using the shared language during the postlesson discussion, Team B linked their anticipations of student thinking during the planning and their lesson observations. The use of a shared language during postlesson discussions also allowed Team B to discuss teaching actions in relation to student learning goals. These discussions are similar to postlesson discussions during open lessons, another Japanese professional development strategy, where teachers contextualize their actions within curricular goals (Miyakawa \& Winsløw, 2013). In addition, the moves for teaching with technology opened the set of pedagogical strategies for teaching with technology, furthering their development of TPACK. The shared language of the moves for using technology introduced in the methods course eased lesson study 
discussions about how to integrate technology in the research lesson during lesson planning. By having a shared language, the teams anticipated how to lead class discussions using students' responses, thus focusing the teams' attention on creating tasks that reveal student thinking.

An important aspect of our proposed lesson study adaptation is that the prospective teachers teach the revised research lesson. Even though in our study the prospective teachers did not have a chance to teach the revised research lesson because of the limitations on school visits as a result of the COVID-19 pandemic, we saw evidence in Team B's postlesson reflection about the importance of engaging prospective teachers in the reteaching step. Mr. García held the prospective teachers accountable for introducing the changes that they suggested to the lesson plan. In doing so, the prospective teachers showed their mutual accountability and motivation for improving instruction, thus building a professional community. Prior research has identified that the lesson revision process is a key aspect of lesson study. Estrella et al. (2020) found that in-service teachers engaged in lesson study had developed strategies for maintaining the cognitive demand of tasks through the lesson revision process. Skultety et al. (2017) identified that the lesson revision was a crucial step for solidifying the knowledge generated in the postlesson discussions of student thinking. In the current study, the prospective teachers in Team B asserted their agency by proposing modifications to the research lesson motivated by their responsibility for coteaching a revised version of the research lesson. The reteaching step is deemed optional in the theoretical model for lesson study (Lewis et al., 2009). Other implementations with prospective teachers do not have the opportunity to teach the revised lesson (e.g., Amador \& Carter, 2016; Bieda et al., 2015). The difficulties of scheduling field experiences so that the reteaching happens in two different class periods covering the same content, and the potential challenge for prospective teachers to coteach a sophisticated lesson that integrates novel technology, are issues to consider in future enactments of the model. At the same time, our study provides initial evidence that increasing prospective teachers' responsibilities by asking them to teach the revised lesson can empower them. Empowering teachers to develop and share knowledge of mathematics teaching is a fundamental component of an infrastructure that supports instructional improvement (Miyakawa \& Winsløw, 2019). Prior research pertaining to lesson study in teacher education programs has revealed the need to develop institutional supports (Epilane, 2012). Future work should continue to build such an infrastructure through the convergence of teacher educators, mentors, and prospective teachers in a hybrid space.

As we continue to develop the lesson study adaptation, we have yet to explore other ways to strengthen the connections between the methods course and the field experience. In our study, each team had a chance to share their lesson plans in the methods course. This exchange enabled discussions across teams about ways to integrate technology in math instruction and feedback from the methods course instructor for improving the research lesson. Moreover, the discussion validated the knowledge stemming from their field experiences in the methods course. Course assignments in the methods course can draw on the field experience, thus solidifying opportunities for creating connections between academic and practitioner knowledge. For example, new journal prompts can include questions about the instructional materials research step or the mathematical content of the lessons. Overall, allowing for a flow of knowledge between the methods course and the field experiences supports the creation of a hybrid space.

The implementation of lesson study in other contexts outside of Japan calls for modifications that consider the idiosyncrasies of local contexts. The Danish experiment with prospective secondary mathematics teachers provides one example of a successful lesson 
study adaptation (Rasmussen, 2016). Our innovation, situated in Puerto Rico, provides proof that lesson study is a viable activity in teacher education programs for creating a hybrid space that connects academic and practitioner knowledge.

Acknowledgements An earlier version of this paper was presented at the 2021 Association of Mathematics Teacher Education virtual conference. The work was supported by a project funded by the National Science Foundation, Division of Undergraduate Education (\#1930950 \& \#1930971 granted to Omar Hernández Rodríguez, PI; Wanda Villafañe Cepeda, Co-PI; and Gloriana González, PI). Any opinions, findings, conclusions or recommendations presented are only those of the investigators; and do not necessarily reflect the views of the National Science Foundation.

Funding The research described in this article was supported by a National Science Foundation's grant to Gloriana González, Omar Hernández-Rodríguez, and Wanda Villafañe-Cepeda for the project entitled "Developing Technological Pedagogical Content Knowledge of Pre-Service Math Teachers by Enhancement of Methods Course Using Instrumental Orchestration," Grant No. DUE-1930950 and DUE-1930971. Opinions, findings, conclusions, or recommendations are those of the authors and do not necessarily reflect the views of the National Science Foundation.

\section{References}

Amador, J. M., \& Carter, I. S. (2016). Audible conversational affordances and constraints of verbalizing professional noticing during prospective teacher Lesson Study. Journal of Mathematics Teacher Education. https://doi.org/10.1007/s10857-016-9347-x

Association of Mathematics Teacher Educators. (2017). Standards for Preparing Teachers of Mathematics. Available online at amte.net/standards.

Ball, D. L., \& Cohen, D. K. (1999). Developing practice, developing practitioners: Toward a practice-based theory of professional education. In G. Sykes \& L. Darling-Hammond (Eds.), Teaching as the learning profession: Handbook of policy and practice (pp. 3-32). Jossey-Bass.

Ball, D. L., \& Forzani, F. M. (2011). Building a common core for learning to teach and connecting professional learning to practice. American Educator. https://doi.org/10.1177/0022487108324554

Bhabha, H. (1990). The third space. In J. Rutherford (Ed.), Identity, community, culture and difference (pp. 207-221). Lawrence and Wishart.

Bieda, K. N., Cavanna, J., \& Ji, X. (2015). Mentor-guided lesson study as a tool to support learning in field experiences. Mathematics Teacher Educator, 4(1), 20-31.

Choque-Dextre, Y., Moreno-Concepción, J., Hernández-Rodríguez, O., Villafañe-Cepeda, W., \& González, G. (2020). Technological knowledge of mathematics pre-service teachers at the beginning of their methodology courses. In A. I. Sacristán, J. C. Cortés-Zavala, \& P. M. Ruiz-Arias, (Eds.), Proceedings of the 42nd annual meeting of the North American Chapter of the International Group for the Psychology of Mathematics Education (pp. 892-894). Mazatlán, Sinaloa, México: Cinvestav. https:/doi. org/https://doi.org/10.51272/pmena.42.2020

Clift, R., \& Brady, P. (2005). Research on methods courses and field experiences. In M. Cochran-Smith \& K. Zeichner (Eds.), Studying teacher education (pp. 309-424). Routledge.

Darling-Hammond, L., Hammerness, K., Grossman, P., Rust, F., \& Shulman, L. (2005). The design of teacher education programs. Preparing teachers for a changing world: What teachers should learn and be able to do, 390-441.

Departamento de Educación de Puerto Rico. (2014). Estándares de contenido y expectativas de grado: Programa de Matemáticas (Puerto Rico Core Standards). San Juan, PR: Author.

Elipane, L. E. (2012). Integrating the essential elements of lesson study in pre-service mathematics teacher education [Doctoral dissertation, University of Copenhagen]. https://www.researchgate.net/publication/323856354_Integrating_the_Essential_Elements_of_Lesson_Study_in_Pre-service_Mathematics_ Teacher_Education

Estrella, S., Zakaryan, D., Olfos, R., \& Espinoza, G. (2020). How teachers learn to maintain the cognitive demand of tasks through Lesson Study. Journal of Mathematics Teacher Education, 23, 293-310.

Fernandez, C. (2002). Learning from Japanese approaches to professional development: The case of Lesson Study. Journal of Teacher Education, 53(5), 393-405. 
Fernandez, M. L., \& Zilliox, J. (2011). Investigating approaches to lesson study in prospective mathematics teacher education. In L. C. Hart, A. S. Alston, \& A. Murata (Eds.), Lesson study research and practice in mathematics education (pp. 85-102). Springer.

Gutiérrez, K. D., Baquedano-López, P., \& Tejeda, C. (1999). Rethinking diversity: Hybridity and hybrid language practices in the third space. Mind, Culture, and Activity, 6(4), 286-303.

Harris, J., Mishra, P., \& Koehler, M. (2009). Teachers' technological pedagogical content knowledge and learning activity types: Curriculum-based technology integration reframed. Journal of Research on Technology in Education, 41(4), 393-416.

Herbst, P. (2011). Promoting and Managing Students' Discourse. University of Michigan: Research Collections: School of Education. http://deepblue.lib.umich.edu/handle/2027.42/84368

Herbst, P., Nachlieli, T., \& Chazan, D. (2011). Studying the practical rationality of mathematics teaching: What goes into "installing" a theorem in geometry? Cognition and Instruction, 29(2), 218-255.

Kilpatrick, J., Swafford, J., \& Findell, B. (Eds.). (2001). Adding it Up: Helping Children Learn Mathematics. National Academy Press.

Grossman, P., Compton, C., Igra, D., Ronfeldt, M., Shahan, E., \& Williamson, P. W. (2009). Teaching practice: A cross-professional perspective. Teachers College Record, 111(9), 2055-2100.

Horn, I. S. (2010). Teaching replays, teaching rehearsals, and re-visions of practice: Learning from colleagues in a mathematics teacher community. Teachers College Record, 112(1), 225-259.

Incikabi, L., \& Kacar, A. (2017). Analyzing prospective mathematics teachers' development of teaching practices in mathematics: A lesson study approach. In J. Keengwe \& G. Onchwari (Eds.), Handbook of research on learner-centered pedagogy in teacher education and professional development (pp. 206-225). IGI Global.

Koehler, M. J., \& Mishra, P. (2005). What happens when teachers design educational technology? The development of technological pedagogical content knowledge. Journal of Educational Computing Research Environmental Science and Technology, 32(2), 131-152. https://doi.org/10.1021/acs.est.6b04302

Lave, J., \& Wenger, E. (1991). Situated learning legitimate peripheral participation. Cambridge University Press.

Lewis, C. C., Perry, R. R., \& Hurd, J. (2009). Improving mathematics instruction through lesson study: A theoretical model and North America case. Journal of Mathematics Teacher Education, 12, 285-304.

Lortie, D. C. (1975). Schoolteacher: A sociological study. University of Chicago Press.

Miyakawa, T., \& Winsløw, C. (2013). Developing mathematics teacher knowledge: The paradidactic infrastructure of "open lesson” in Japan. Journal of Mathematics Teacher Education, 16, 185-209.

Miyakawa, T., \& Winsløw, C. (2019). Paradidactic infrastructure for sharing and documenting mathematics teacher knowledge: A case study of "practice research" in Japan. Journal of Mathematics Teacher Education, 22, 281-303.

National Governors Association Center for Best Practices, Council of Chief State School Officers [NGAC]. (2010). Common core state standards for mathematics. Washington D.C.: Author.

National Research Council. (2000). How people learn: Brain, mind, experience, and school, J. Bransford, J., Pellegrino, D. Berliner, M. Cooney, A. Eisenkraft, H. Ginsburg, et al. (Eds.). Washington, DC: National Academy Press.

Peressini, D., Borko, H., Romagnano, L., Knuth, E., \& Willis, C. (2004). A conceptual framework for learning to teach secondary mathematics: A situative perspective. Educational Studies in Mathematics, $56(1), 67-96$.

Rasmussen, K. (2016). Lesson study in prospective mathematics teacher education: Didactic and paradidactic technology in the post-lesson reflection. Journal of Mathematics Teacher Education, 19, 301-324. https://doi.org/10.1007/s10857-015-9299-6

Siegel, S., \& Castellan, N. J. (1988). Nonparametric statistics for the behavioral sciences (2nd ed.). McGraw-Hill.

Skultety, L., González, G., \& Vargas, G. (2017). Using technology to support teachers' lesson adaptations during Lesson Study. Journal of Technology and Teacher Education, 25(2), 5-33.

Takahashi, A. (2014). The role of the knowledgeable other in Lesson Study: Examining the final comments of experienced Lesson Study practitioners. Mathematics Teacher Education and Development, 16(1), 1-17.

Wake, G., Swan, M., \& Foster, C. (2016). Professional learning through the collaborative design of problem-solving lessons. Journal of Mathematics Teacher Education, 19(2-3), 243-260.

Zeichner, K. (2010). Rethinking the connections between campus courses and field experiences in collegeand university-based teacher education. Journal of Teacher Education, 61(1-2), 89-99. https://doi.org/ $10.1177 / 0022487109347671$

Publisher's Note Springer Nature remains neutral with regard to jurisdictional claims in published maps and institutional affiliations. 